\title{
Mengukur Kinerja Keuangan PT. Pegadaian (Persero) Dengan Menggunakan Rasio Keuangan
}

\author{
Andreas Rudiwantoro
}

Universitas Bina Sarana Informatika

e-mail: andreas.aed@bsi.ac.id

\begin{tabular}{ccc}
\hline Diterima & Direvisi & Disetujui \\
$24-07-2020$ & $05-09-2020$ & $21-09-2020$ \\
\hline
\end{tabular}

\begin{abstract}
Abstrak - Pengukuran kinerja keuangan suatu perusahaan dapat dilakukan dengan menganalisis laporan keuangan perusahaan. Analisis rasio merupakan alat untuk mengukur kinerja keuangan perusahaan. Beberapa rasio tersebut adalah rasio profitabilitas (Pendapatan Operasional terhadap Total Aset, Return on Asset, Return on Equity dan Net Profit Margin), rasio solvabilitas (Total Debt to Total Asset dan Total Debt to Total equity), dan rasio pertumbuhan terakhir operasional. pendapatan, laba operasi dan total aset. Objek penelitian adalah PT. Pegadaian (Persero). Fokus penelitian adalah laporan keuangan perusahaan yang terdiri dari neraca dan laporan laba rugi periode 2015-2019. Jenis penelitian ini adalah penelitian deskriptif. Sumber data yang digunakan adalah data sekunder yang diunduh di situs http://www.pegadaian.co.id. Teknik pengumpulan data yang digunakan dalam penelitian ini adalah dokumentasi. Analisis data yang digunakan dalam penelitian ini adalah analisis deskriptif dengan menggunakan analisis rasio keuangan. Tujuan penelitian ini adalah untuk mengetahui kinerja keuangan PT. Pegadaian (Persero) dalam hal analisis rasio keuangan. Hasil pengukuran dengan menggunakan analisis rasio menunjukkan bahwa kinerja keuangan PT. Pegadaian (Persero) selama 5 tahun cukup baik.
\end{abstract}

Kata Kunci: Analisis, Rasio Keuangan, Dan Kinerja Keuangan

Abstract - Measurement of a company's financial performance can be done by analyzing the company's financial statements. Ratio analysis is tool to measure a company's financial performance. Some of these ratios are profitability ratio (Operating Revenues to Total Asset, Return on Asset, Return on Equity and Net Profit Margin), solvency ratio (Total Debt to Total Asset and Total Debt to Total equity), and the last growth ratio of operating revenues, operating profit and total asset. The object of research is PT. Pegadaian (Persero). The focus of the study is the company's financial statements consisting of balance sheet and income statements for the period 2015 2019. This type of research is description research. The data source used is secondary data downloaded on the site http://www.pegadaian.co.id. Data collection techniques used in this study are documentation. Analysis of the data used in this research is description analysis using financial ratio analysis. The purpose of this study was to determine the financial performance of PT. Pegadaian (Persero) in terms of financial ratio analysis. The measurement results using ratio analysis shows that the financial performance of PT. Pegadaian (Persero) for 5 years is quite good.

Keywords: Analysis, Financial Ratios, And Financial Performances

\section{PENDAHULUAN}

Bagi kalangan akademisi, investor dan para pemangku kepentingan dalam sebuah perusahaan, tentu tidak asing lagi dengan istilah rasio keuangan. Rasio ini merupakan teknik perhitungan yang menjadi salah satu parameter untuk menentukan kebijakan dalam menjalankan operasional perusahaan atau menjadi dasar dalam pengambilan keputusan ekonomi ke depan.

Rasio keuangan atau yang disebut juga analisis rasio keuangan, merupakan suatu alat untuk menganalisadan mengukur kinerja keuangan perusahaan apakah dalam kondisi sehat atau tidak.

Dapat dipertegas bahwa rasio keuangan dapat memberikan informasi yang berkaitan dengan keuangan, kemajuan perusahaan serta untuk mengukur kinerja manajemen.

Bahan baku untuk melakukan analisis rasio bersumber dari laporan keuangan perusahaan yang diterbitkan untuk periode tertentu. Rasio keuangan merupakan metode yang digunakan untuk melakukan analisis dengan menghitung nilai rata rataterhadap laporan keuangan dan menjelaskan suatu hubungan 
antara suatu jumlah tertentu dengan jumlah yang lain dalam laporan keuangan tersebut.

Perbandingan yang dilakukan terhadap pos pos dalam laporan keuangan diharapkan menghasilkan suatu perbandingan yang logis dan dapat dipertanggung jawabkan, yang pada tahap berikutnya mempunyai manfaat tertentu sebagai pedoman dalam pengambilan keputusan.

Analisis laporan keuangan perlu dilakukan secara cermat dengan menggunakan metode dan teknik yang tepat sehingga hasil yang diharapkan benar-benar tepat pula. Kesalahan dalam memasukkan angka atau rumus akan berakibat pada tidak akuratnya hasil yang hendak dicapai. Kemudian, hasil perhitungan tersebu, dianalisis dan diinterpreta-sikan sehingga diketahui posisi keuangan yang sesungguhnya. Kesemuanya ini harus dilakukan secara teliti, mendalam dan jujur (Kasmir, 2010)

Bahan dasar dalam penelitian, menggunakan laporan keuangan yang diterbitkan oleh PT. Pegadaian (Persero) dari tahun 2015 sampai tahun 2019. Laporan keuangan tersebut penulis unduh di (https://www.pegadaian.co.id), website resmi PT. Pegadaian (Persero).

Merujuk pada situs (https://wikipedia.org), pegadaian adalah sebuah Badan Usaha Milik Negara (BUMN) sektor keuangan Indonesia yang bergerak pada lini bisnis pembiayaan, emas dan aneka jasa.

Layanan pembiayaan meliputi kredit cepat aman, kredit angsuran fidusia dan kredit angsuran sistem gadai. Layanan emas meliputi murabahah mulia untuk investasi abadi dan tabungan emas. Layanan aneka jasa meliputi jasa pembayaran tagihan listrik, telepon, air, tv langganan, internet, finance, pulsa handphone, pengiriman uang ke dalam negeri dan keluar negeri serta tiket kereta.

Dewasa ini industri gadai telah mengalami perubahan yang sangat dratis. Ditandai dengan maraknya kehadiran perusahaan gadai swasta dan maraknya kehadiran perusahaan financial technology (fintech) serta maraknya layanan substitusi yang ditawarkan oleh perbankan dan perusahaan pembiayaan.

Menghadapi kondisi persaingan pasar yang ketat tersebut, perum pegadaian terus melakukan pembenahan. Sejak tahun 2017 hingga saat ini secara berkelanjutan perusahaan terus melakukan pengembangan produk dan layanan yang berbasis teknologi digital untuk memberikan kemudahan kepada para pelanggan/konsumen.

Pihak perusahaan juga melakukan pengembangan channel distribution melalui agen pegadaian untuk meningkatkan inklusi keuangan.

Bersumber pada harian Kontan online bahwa per tanggal 27 Agustus 2018, Pemerintah melalui Otoritas Jasa Keuangan (OJK) telah memberikan tanda terdaftar dan berizin kepada 50 perusahaan gadai baru di Indonesia (www.kontan.co.id, 2018).

Penambahan perusahaan gadai swasta baru tersebut tidak berpengaruh secara signifikan terhadap laju pertumbuhan PT. Pegadaian (Persero) milik pemerintah. Hal ini disebabkan pegadaian swasta tersebut cenderung mencari alternatif untuk bertahan dan berkompetisi dengan PT. Pegadaian (Persero). Perusahaan pegadaian swasta beroperasi di luar jam kerja dan mengambil nasabah yang belum terjangkau oleh pegadaian milik pemerintah (www.kontan.co.id, 2018).

Kehadiran perusahaan pegadaian swasta tidak berdampak signifikan pada lini usaha PT. Pegadaian (Persero) dapat dilihat pada tabel 1 di bawah ini . Tabel tersebut menyajikan beberapa data keuangan PT. Pegadaian (Persero) dari tahun 2015 sampai 2019

\begin{tabular}{cccc}
\multicolumn{2}{l}{ Tabel 1. Data Keuangan } & & (milliard Rp) \\
\hline Tahun & T. Asset & Net Income & T. Expense \\
\hline & & & \\
2015 & 39.158 & 1.938 & 6.328 \\
\hline & & & \\
2016 & 46.874 & 2.210 & 6.708 \\
\hline & & & \\
2017 & 48.687 & 2.514 & 7.185 \\
\hline & 52.791 & 2.775 & 7.830 \\
\hline & & \\
2018 & 65.324 & 3.108 & 9.152 \\
\hline Sumber: Laporan Keuangan PT Pegadaian
\end{tabular}

Berdasar tabel 1 tersebut diatas kita dapat mengetahui bahwa total biaya operasional terus mengalami peningkatan dari tahun ke tahun. Kenaikan biaya operasional terbesar berasal dari beban bunga, beban administrasi dan umum. Jumlah beban operasional perusahaan yang meningkat setiap tahunnya berbanding lurus terhadap pertumbuhan total assets dan pertumbuhan laba bersih. Ini dapat disimpulkan bahwa kinerja PT. Pegadaian (Persero) sangat mampu bertahan ditengah kondisi persaingan yang ketat.

Pada tahun buku 2019, PT. Pegadaian (Persero) masih mampu membukukan pertumbuhan asset sebesar 65.324 milliard rupiah dan laba bersih tumbuh sebesar 3.108 milliard rupiah.

Raihan kinerja yang sangat positif ini, membuat penulis tertarik untuk mendalami lebih lanjut atas kinerja keuangan perusahan dengan menggunakan rasio keuangan. Dalam hal ini rasio yang akan dibahas adalah rasio profitabilitas, rasio solvabilitas dan rasio pertumbuhan. Tiga jenis rasio ini menjadi alat untuk mengukur dan melihat kinerja keuangan perusahaan PT. Pegadaian (Persero).

\section{Laporan Keuangan Perusahaan}

Menurut (Hery, 2012) laporan keuangan adalah hasil dari proses akuntansi yang dapat digunakan sebagai alat untuk mengkomunikasikan data keuangan atau aktivitas perusahaan kepada pihak pihak yang berkepentingan. Dengan kata lain sebagai alat informasi yang menghubungkan perusahaan dengan pihak-pihak yang berkepen-tingan, yang menunjukkan kondisi kesehatan keuangan 
perusahaan dan kinerja perusahaan.

Menurut (Ikatan Akuntan Indonesia, 2009), laporan keuangan adalah suatu penyajian terstruktur dari posisi keuangan dan kinerja keuangan suatu entitas. Jadi laporan keuangan merupakan salah satu informasi yang sangat penting dalam menilai perkembangan perusahaan. Laporan keuangan dapat digunakan untuk menilai prestasi yang dicapai perusahaan pada saat lampau, sekarang dan rencana pada waktu yang akan datang (Maith, 2013).

Laporan keuangan menurut (Munawir, 2007), adalah hasil proses akuntansi yang dapat digunakan sebagai alat untuk berkomunikasi antara data keuangan atau aktivitas suatu perusahaan dengan pihak-pihak yang bersang-kutan dengan data atau aktivitas perusahaan tersebut.

Selanjutnya pengertian laporan keuangan menurut (Kasmir, 2010), adalah laporan yang menunjukkan kondisi keuangan perusahaan pada saat ini atau dalam suatu periode tertentu.

Merujuk pada beberapa pengertian laporan keuangan tersebut diatas dapat disimpulkan bahwa laporan keuangan adalah suatu hasil proses akuntansi yang penyajian dilakukan secara sistematik dan terstruktur untuk menggambarkan posisi keuangan perusahaan pada periode tertentu yang kemudian laporan keuangan tersebut dapat digunakan sebagai alat komunikasi antar pihak pihak yang berkepentingan.

Mengacu pada (Ikatan Akuntan Indonesia, 2009), tentang penyajian laporan keuangan, ada 5 komponen penting yaitu: (1) laporan posisi keuangan, umumnya disebut neraca, (2) laporan laba rugi, (3) laporan perubahan modal, (4) laporan catatan atas laporan keuangan dan (5) laporan arus kas.

Masing masing komponen dalam laporan keuangan memiliki tujuan dan maksud tersendiri. Neraca untuk menggambarkan posisi keuangan perusahaan pada periode tertentu yang terdiri dari harta, hutang dan modal. Laporan laba rugi untuk menggambarkan kondisi usaha atau kinerja suatu perusahaan dalam suatu periode tertentu. Laporan perubahan modal menggambarkan jumlah modal yang dimiliki perusahaan untuk periode tertentu. Memberikan informasi sebab sebab terjadinya perubahan modal. Laporan catatan atas laporan keuangan memberikan informasi tentang penjelasan yang dianggap perlu atas laporan keuangan agar pengguna laporan keuanmgan dapat memahami secara jelas atas laporan kuangan yang disajikan. Laporan arus kas menunjukkan arus kas masuk dan arus kas keluar perusahaan.

Laporan keuangan menjadi pintu utama dalam menilai kinerja manajemen perusahaan. Penilaian kinerja atas perusahaan akan menjadi patokan atau ukuran apakah manajemen mampu atau berhasil dalam menjalankan kebijakan yang telah digariskan.

\section{Kinerja Keuangan Perusahaan}

Menurut (Jumingan, 2006), kinerja keuangan adalah gambaran kondisi keuangan perusahaan pada suatu periode tertentu baik menyangkut aspek penghimpunan dana maupun penyaluran dana, yang biasanya diukur dengan indikator kecukupan modal, likuiditas dan profitabilits.

Kinerja keuangan perusahaan merupakan prestasi yang dicapai perusahaan dalam suatu periode tertentu yang mencerminkan tingkat kesehatan perusahaan tersebut (Sutrisno, 2009). Kinerja keuangan adalah suatu analisis yang dilakukan untuk melihat sejauh mana suatu perusahaan telah melaksanakan dengan menggunakan aturan-aturan pelaksanaan keuangan secara baik dan benar. Kinerja perusahan merupakan suatu gambaran tentang kondisi keuangan suatu perusahaan yang dianalisis dengan alat-alat analisis keuangan, sehingga dapat diketahui mengenai baik buruknya keadaan keuangan suatu perusahaan yang mencerminkan prestasi kerja dalam periode tertentu. Hal ini sangat penting agar sumber daya digunakan secara optimal dalam menghadapi perubahan lingkungan (Fahmi, Analisis Laporan Keuangan, 2011)

Kinerja keuangan perusahaan berkaitan erat dengan pengukuran dan penilaian kinerja. Pengukuran kinerja (performing measurement) adalah kualifikasi dan efisiensi serta efektivitas perusahaan dalam pengoperasian bisnis selama periode akuntansi.

Penilaian kinerja menurut (Srimindarti, 2006), adalah penentuan efektivitas operasional, organisasi dan karyawan berdasarkan sasaran, standard dan kriteria yang telah ditetapkan sebelumnya secara periodik.

Pengukuran kinerja digunakan perusahaan untuk melakukan perbaikan diatas kegiatan operasionalnya agar dapat bersaing dengan perusahaan lainnya. Analisis kinerja keuangan merupakan proses pengkajian secara kritis terhadap review data, menghitung, mengukur, menginterprestasi dan memberi solusi terhadap keuangan perusahaan pada suatu periode tententu.

Menurut (Munawir, 2012), ada empat tujuan pokok dari pengukuran kinerja keuangan perusahaan, yaitu:

a. Mengetahui tingkat likuiditas. Likuiditas menunjukkan kemampuan suatu perusahaan untuk memenuhi kewajiban keuangan yang harus segera diselesaikan pada saat ditagih.

b. Mengetahui tingkat solvabilitas. Solvabilitas menunjukkan kemampuan perusahaan untuk memenuhi kewajiban keuangannya apabila perusahaan tersebut dilikuidasi, baik keuangan jangka pendek maupun jangka panjang.

c. Mengetahui tingkat rentabilitas. Rentabilitas atau yang sering disebut dengan profitabilitas menunjukkan kemampuan perusahaan untuk menghasilkan laba selama periode tertentu.

d. Mengetahui tingkat stabilitas. Stabilitas menunjukkan kemampuan perusahaan untuk 
melakukan usahanya dengan stabil yang diukur dengan mempertimbangkan kemampuan perusahaan untuk membayar hutang-hutangnya serta membayar beban bunga atas hutang tersebut tepat pada waktunya

Menurut (Harjito \& Martono, 2011), kinerja keuangan suatu perusahaan sangat bermanfaat bagi berbagai pihak seperti investor, kreditur, analis, konsultan keuangan, pialan, pemerintah dan pihak manajemen sendiri.

Salah satu cara yang dipakai untuk menilai kinerja perusahaan untuk pengmbilan keputusan investasi adalah melalui analisis rasio keuangan (Barus, Sudjana, \& Sulasmiyati, 2017). Analisis ini merupakan teknik analisis keuangan untuk mengetahui hubungan diantara pos tertentu dalam neraca maupun dalam laporan laba rugi.

\section{Analisis Rasio Keuangan}

Analisis rasio keuangan merupakan kegiatan membandingkan angka angka yang ada dalam laporan keuangan dengan cara membagi satu angka dengan angka lainnya. Perbandingan dapat dilakukan antara satu komponen dengan komponen dalam satu laporan keuangan. Hasil rasio keuangan ini digunakan untuk menilai kinerja perusahaan dalam satu periode tertentu.

Analisis rasio menurut pendapat (Munawir, 2007), adalah suatu metode analisis untuk mengetahui hubungan dari pos pos tertentu dalam neraca atau laporan laba rugi secara individual atau kombinasi dari kedua laporan tersebut.

Penggolongan atau pengelompokan rasio bermacam macam. Apabila dilihat dari sumbernya dari mana rasio itu disusun, maka menurut (Riyanto, 2001), dapat digolongkan dalam tiga golongan, yaitu:

a. Rasio-rasio neraca. Rasio yang disusun dari data yang berasal dari neraca (balance sheet ratio).

b. Rasio-rasio laporan laba rugi. Rasio yang disusun dari data yang berasal dari laporan laba rugi perusahaan (income statement ratio).

c. Rasio-rasio antar laporan. Rasio yang disusun dari data yang berasal dari neraca dan data lainnya berasal dari laporan laba rugi (interstatement ratios)

Analisis rasio keuangan yang akan Penulis gunakan atau ulas dalam jurnal ilmiah ini adalah sebagai berikut:

\section{A. Rasio Profitabilitas atau Rentabilitas}

Rasio untuk mengukur seberapa besar kemampuan perusahaan memperoleh laba dalam hubungannya dengan nilai penjualan, aktiva dan modal sendiri. Semakin tinggi nilai prosentase rasio profitabilitas menunjukkan kondisi keuangan perusahaan yang semakin baik.

Senada dengan (Kasmir, 2010), rasio profitabilitas merupakan rasio untuk menilai kemampuan perusahaan dalam mencari keun- tungan. Dalam penggunaanya, rasio ini untuk menunjukkan tingkat efisiensi perusahaan.

Penggunaan rasio profitabilitas dapat dilakukan dengan membandingkan antara berbagai komponen yang ada di laporan keuangan terutama neraca dan laporan laba rugi. Pengukuran dapat dilakukan untuk beberapa periode akuntansi. Tujuannya adalah agar terlihat perkembangan perusahaan dalam rentang waktu tertentu, baik penurunan atau kenaikan, sekaligus mencari penyebab perubahan tersebut. Beberapa rasio profitabiltas adalah sebagai berikut:

1. Interest Income To Total Assets.

Rasio ini membandingkan antara komponen pendapatan dengan total aktiva yang dimiliki perusahaan. Istilah penggunaan interest income karena objek penelitian berupa perusahaan jasa yaitu PT. Pegadaian (Perseroan). Rumus yang digunakan adalah (Interest Income : Total Assets) X 100\%. Interest Income merupakan jumlah nilai dari pendapatan jasa kotor dalam suatu periode tertentu.

Semakin tinggi prosentase yang dihasilkan berarti semakin besar kemampuan perusahaan dalam menghasilkan pendapatan dari total assets yang dimiliki.

2. Return On Assets (ROA)

Rasio ini untuk menilai prosentase laba bersih yang diperoleh perusahaan terkait sumber daya atau total asset sehingga efisiensi suatu perusahaan dalam mengelola assetnya dapat terlihat.

Rasio ini digunakan untuk mengukur kemampuan manajemen dalam memperoleh profitabilitas dan manajerial efisiensi secara overall (Kasmir, 2010). Rumus yang digunakan adalah (Net Profit : Total Assets) X 100\%.

Makin besar ROA menunjukkan tingkat keuntungan yang diraih perusahaan semakin baik dan menunjukkan semakin baik juga posisi perusahaan dalam pengelolaan asset yang dimiliki. Semakin tinggi nilai prosentase ROA semakin baik produktivitas asset menciptakan laba bersih.

\section{Return On Equity (ROE)}

Rasio ini digunakan untuk mengukur kemampuan perusahaan dalam memperoleh laba yang tersedia bagi pemegang saham perusahaan. Rasio ini merupakan ukuran profitabilitas dari sudut pandang pemegang saham (Barus, Sudjana, \& Sulasmiyati, 2017).

Hasil pengembalian ekuitas atau return on equity atau rentabilitas modal sendiri merupakan rasio untuk mengukur laba bersih sesudah pajak dengan modal sendiri. Semakin tinggi rasio ini, semakin baik. Artinya posisi pemilik kuat, demikian pula sebaliknya (Kasmir, 2010). Rumus untuk mencari return on Equity dapat menggunakan rumus sebagai berikut: (Net Profit : Equity) X 100\%. 


\section{Net Profit Margin}

Rasio ini disebut juga sebagai margin laba bersih yang digunakan sebagai alat ukur laba bersih yang diperoleh dalam setiap nilai penjualan dan mengukur seluruh efisiensi produksi, administrasi maupun manajemen pajak.

Fungsi dari penggunaan rasio ini untuk melihat setiap nilai rupiah dari laba bersih yang dihasilkan oleh satu rupiah penjualan.

Rasio net profit margin atau margin laba atas penjualan merupakan salah satu rasio yang digunakan untuk mengukur margin laba atas penjualan. Cara pengukuran rasio ini adalah dengan membandingkan laba bersih setelah pajak dengan penjualan bersih (Kasmir, 2010). Rumus yang digunakan adalah: (Net Profit : Net Sales) $X 100 \%$.

\section{B. Rasio Solvabilitas}

Rasio ini digunakan untuk mengukur kemampuan perusahaan untuk membayar seluruh kewajiban, baik jangka pendek maupun jangka panjang apabila perusahaan dibubarkan (dilikuidasi). Rasio solvabilitas merupakan rasio untuk mengukur sejauh mana aktiva perusahaan dibiayai dengan hutang.

Dengan analisis rasio solvabilitas, perusahaan akan mengetahui beberapa hal berkaitan dengan penggunaan modal sendiri dan modal pinjaman serta mengetahui rasio kemampuan perusahaan untuk memenuhi kewajibannya. Setelah diketahui, manajer keuangan dapat mengambil kebijakan yang dianggap perlu guna menyeimbangkan penggunaan modal. Akhirnya, dari rasio ini kinerja manajemen selama ini akan terlihat apakah sesuai tujuan perusahaan atau tidak (Kasmir, 2010).

Menurut (Sartono, 2011), Rasio solvabilitas adalah rasio yang menunjukkan kapasitas perusahaan untuk memenuhi kewajiban jangka pendek maupun jangka panjang.

Dalam pratiknya, terdapat beberapa jenis rasio solvabilitas yang dapat digunakan perusahaan. Tetapi dalam penelitian ini, penulis hanya akan menggunakan dua jenis rasio solvabilitas, yaitu:

\section{Debt To Assets Ratio (Debt Ratio)}

Debt ratio merupakan rasio hutang yang digunakan untuk mengukur perbandingan antara total hutang dengan total aktiva. Dengan kata lain, seberapa besar aktiva perusahaan dibiayai oleh hutang atau seberapa besar hutang perusahaan berpengaruh terhadap pengelolaan aktiva (Kasmir, 2010).

Dari hasil pengukuran, apabila rasionya tinggi, artinya pendanaan dengan hutang semakin banyak, maka semakin sulit bagi perusahaan untuk memperoleh tambahan pinjaman karena dikhawatirkan perusahaan tidak mampu menutupi hutang-hutangnya dngan aktiva yang dimilikinya.

Demikian pula apabila rasionya rendah, semakin kecil perusahaan dibiayai dengan hutang. Artinya kebutuhan operasional perusahaan lebih banyak dibiayai dari modal sendiri.

Untuk mencari debt ratio menggunakan rumus (Total Debt : Total Assets)

2. DebtTo Equity Ratio

Merupakan rasio perbandingan antara total hutang dengan modal sendiri yang berupa saham dan surat-surat berharga lainnya.

Menurut (Kasmir, 2010), debt to equity ratio merupakan rasio yang digunakan untuk menilai hutang dengan ekuitas. Rasio ini berguna untuk mengetahui jumlah dana yang disediakan peminjam(kreditor) dengan pemilik perusahaan. Dengan kata lain, rasio ini berfungsi untuk mengetahui setiap rupiah modal sendiri yang dijadikan untuk jaminan hutang atau seberapa besar bagian dari keseluruhan kebutuhan dana yang didanai dengan hutang. Rumus (Total Debt : Total Equity).

\section{Rasio Pertumbuhan / Growth Ratio}

Definisi rasio pertumbuhan menurut (Fahmi, 2012) adalah rasio yang mengukur seberapa besar kemampuan perusahaan dalam mempertahankan posisinya di dalam industri dan dalam perkembangan ekonomi secara umum.

Pendapat lain mengatakan bahwa rasio pertumbuhan merupakan rasio yang menggambarkan kemampuan perusahaan dalam mempertahankan posisi ekonominya di tengah pertumbuhan perekonomian dan sektor usahanya (Kasmir, 2010).

Dalam rasio pertumbuhan pada umumnya yang menjadi obyek analisis adalah pertumbuhan penjualan, pertumbuhan laba bersih, pertumbuhan pendapatan per saham dan pertumbuhan dividen per saham. Dalam penelitian ilmiah ini penulis hanya akan menggunakan tiga rasio pertumbuhan, yaitu pertumbuhan penjualan, laba bersih dan pendapatan per saham.

Perhitungan rasio pertumbuhan dapat dilakukan dengan rumus yang sederhana, membandingkan antara dua nilai dalam waktu tertentu. Tingkat pertumbuhan akan ditampilkan dalam bentuk prosentase.

Rumus untuk menghitung rasio pertumbuhan adalah ((Nilai Akhir - Nilai Awal) : Nilai Awal) X 100\%. Jika nilai akhir dan nilai awal jumlahnya sama, berarti tidak terdapat pertumbuhan. Jika nilai akhir > nilai awal maka terdapat pertumbuhan yang positif, sebaliknya jika nilai akhir < nilai awal maka terjadi pertumbuhan negatif.

\section{METODE PENELITIAN}

Penelitian ini memiliki tujuan untuk menjelaskan gambaran mengenai kinerja keuangan 
PT. Pegadaian (Persero) tiap periode dari rasio keuangan perusahaan berupa neraca dan laporan laba rugi, sehingga dari gambaran itu dapat diketahui tingkat likuiditas, solvabilitas dan tingkat pertumbuhan perusahaan tersebut.

Populasi dalam penelitian ini adalah laporan keuangan PT. Pegadaian (Persero). Sample yang diambil yaitu laporan keuangan perusahaan yang diterbitkan selama 5 tahun terakhir dari tahun 2015 sampai tahun 2019. Populasi adalah kelompok elemen yang lengkap, yang biasanya berupa objek, transaksi atau kejadian dimana kita tertarik untuk mempelajarinya atau menjadi objek penelitian (Kuncoro, 2009). Sample adalah suatu himpunan bagian (subset) dari unit populasi.

Metode pengumpulan data dalam penelitian ini adalah data sekunder. Data sekunder dapat didefinisikan sebagai data yang dikumpulkan oleh pihak lain (Kuncoro, 2009). Data sekunder dalam penelitian ini berupa laporan keuangan perusahaan yang di unduh melaui situs resmi PT. Pegadaian (Persero) lewat jaringan internet.

Metode analisa dalam penelitian ini adalah metode analisa horizontal. Metode analisa horizontal adalah membandingkan laporan keuangan untuk beberapa periode. Dari hasil analisis ini akan terlihat perkembangan perusahaan dari periode satu ke periode berikutnya (Kasmir, 2010).

\section{HASIL DAN PEMBAHASAN}

\section{Gambaran Umum Perusahaan}

PT. Pegadaian (Persero) didirikan pada pada tanggal 1 April 1901 sebagai perseroan negara dan telah mengalami beberapa kali perubahan status. Saat ini perusahaan berstatus sebagai Perseroan Terbatas (Persero) berdasarkan Peraturan Pemerintah No. 51 Tahun 2011 Tentang Perubahan Bentuk Badan Hukum Perseroan Umum (Perum) Pegadaian.

Perubahan tersebut dituangkan pada Akta Pendirian Perseroan PT. Pegadaian (Perseroan) Nomor 1 tanggal 1 April 2012 yang dibuat dihadapan Notaris Nanda Fauz Iwan, SH., M.Kn., berkedudukan di Jakarta dan disahkan melalui Keputusan Menteri Hukum dan Hak Asasi Manusia Republik No. AHU17525.AH.01.01 Tahun 2012 tanggal 4 April 2012.

Akta Pendirian Perseroan telah diubah beberapa kali, terakhir melalui Akta Notaris Nanda Fauz Iwan, S.H., M.Kn., No. 3 tanggal 5 Desember 2019 dan disahkan melalui Keputusan Menteri Hukum dan Hak Asasi Manusia Republik Indonesia No. AHU.0236352.AH.0.11 Tahun 2019.

Berdasarkan Akta Pendirian, maksud dan tujuan perseroan adalah melakukan usaha dibidang gadai dan fidusia, baik secara konvensional maupun syariah dan jasa lainnya di bidang keuangan sesuai dengan ketentuan peraturan perundang-undangan terutama untuk masyarakat berpenghasilan menengah ke bawah, usaha mikro, usaha kecil dan usaha menengah, serta optimalisasi pemanfaatan sumber daya perseroan dengan menerapkan prinsip perseroan terbatas.

Untuk mencapai maksud dan tujuan tersebut, perseroan menyelenggarakan usaha utama dan lainnya sebagai berikut:

a. Penyaluran pinjaman berdasarkan hukum gadai termasuk gadai efek.

b. Penyaluran pinjaman berdasarkan jaminan fidusia.

c. Pelayanan jasa titipan, pelayanan jasa taksiran dan setifikasi.

d. Jasa transfer uang, jasa transaksi pembayaran dan jasa administrasi pinjaman.

e. Optimalisasi pemanfaatan sumber daya perseroan.

Kantor pusat perseroan berlokasi di jalan Kramat Raya No. 162 Jakarta Pusat, kode pos 10430 dan mempunyai 12 kantor wilayah, 61 kantor area, 642 kantor cabang dan 3.481 kantor unit pelayanan cabang yang tersebar di seluruh wilayah Indonesia.

Manajemen kunci perseroan meliputi dewan komisaris, Direksi, Komite Audit, Komite Manajemen Risiko, Remunerasi dan Nominasi serta Dewan Pengawas Syariah. Pada Tanggal 31 Desember 2019 PT. Pegadaian (Persero) memiliki jumlah karyawan sebanyak 27.786 orang.

\section{Hasil Penelitian}

Menurut (Barus, Sudjana, \& Sulasmiyati, 2017), Perusahaan dapat dikatakan sehat apabila perusahaan dapat bertahan dalam kondisi ekonomi apapun, yang terlihat dari kemampuannya dalam memenuhi kewajiban-kewajiban financial dan melaksanakan operasinya dengan stabil serta dapat menjaga kontinuitas perkembangan usahanya dari waktu ke waktu.

Kinerja suatu perusahaan merupakan hasil dari serangkaian proses dengan mengorbankan berbagai sumber daya. Adapun salah satu parameter kinerja tersebut adalah laba. Laba perusahaan diperlukan untuk kepentingan kelangsungan hidup perusahaan dan ketidakmampuan perusahaan dalam mendapatkan laba akan menyebabkan perusahaan bangkrut atau terlikuidasi.

Berdasarkan analisis rasio guna mengukur kinerja keuangan PT. Pegadaian (Persero), maka didapatkan hasil sebagai berikut:

\section{Rasio Profitabilitas}

Tabel 2. Rasio Profitabilitas

\begin{tabular}{ccccc}
\hline Thn & $\begin{array}{c}\text { Interest } \\
\text { Income To } \\
\text { TTL Asset }\end{array}$ & ROA & ROE & $\begin{array}{c}\text { N. Profit } \\
\text { Margin }\end{array}$ \\
\hline 2015 & $22,61 \%$ & $4,95 \%$ & $15,47 \%$ & $21,89 \%$ \\
\hline 2016 & $20,44 \%$ & $4,72 \%$ & $13,41 \%$ & $23,07 \%$ \\
\hline 2017 & $21,27 \%$ & $5,16 \%$ & $13,80 \%$ & $24,28 \%$ \\
\hline 2018 & $21,23 \%$ & $5,26 \%$ & $13,80 \%$ & $24,77 \%$ \\
\hline 2019 & $19,80 \%$ & $4,76 \%$ & $13,48 \%$ & $24,00 \%$ \\
\hline
\end{tabular}


Sumber: Olahan Data

Pada tabel 2 tersebut di atas, menunjukkan hasil analisis rasio profitabilitas yaitu interest income to total assets, ROA, ROE dan net profit margin untuk periode tahun 2015 sampai dengan tahun 2019.

Hasil perhitungan interest income to total assets pada tahun 2019 sebesar 19,82\%. Prosentase ini memberikan gambaran bahwa setiap satu rupiah assets yang ditanamkan pada perusahaan akan memberikan pendapatan sebesar 19,82\%. Perolehan rasio interest income to total asset tertinggi terjadi tahun 2015, yaitu sebesar 22,61\%.

Hasil perhitungan rasio tahun 2019, jika dibandingkan dengan tahun 2018, mengalami penurunan sebesar $6,64 \%$,. Stagnasi perekonomian nasional sepanjang tahun 2019 menjadi faktor utama penurunan tersebut. Walaupun demikian jika dilihat dalam jumlah nilai uang, baik itu total asset dan pendapatan perusahaan mengalami pening-katan yang cukup signifikan. Total Asset di tahun 2019 tumbuh sebesar 23,74\% dibandingkan tahun 2018. Perolehan pendapatan sewa modal tahun 2019 naik sebesar 15,56\% dibandingkan tahun 2018.

Hasil analisis return on asset (ROA) menunjukkan rasio sebesar 4,76\% di tahun 2019. Hal ini memberikan gambaran bahwa setiap satu rupiah asset yang ditanamkan pada perusahaan akan memberikan nilai keuntungan bersih sebesar $4,76 \%$. Perolehan rasio ROA tertinggi terjadi tahun 2018, yaitu sebesar 5,26\%.

Secara prosentase untuk rasio ROA pada tahun 2019 mengalami penurunan sebesar 9,48\% jika dibandingkan tahun 2018. Tetapi jika dilihat secara jumlah nilai uang, laba bersih di tahun 2019 tumbuh sebesar 11,98\% terhadap tahun 2018, dimana PT. Pegadaian (Persero) membukukan laba bersih sebesar 3,11 triliun rupiah pada tahun 2019.

Hsail analisis untuk rasio ROE dari tahun 2015 sampai tahun 2019 berturut-turut adalah sebagai berikut; $15,47 \%, 13,41 \%, 13,80 \%, 13,80 \%$, dan tahun 2019 sebesar 13,48\%. Prosentase tertinggi untuk rasio ROE terjadi di tahun 2015. Mengacu pada ROE tahun 2019, sebesar 13,48\% menunjukkan bahwa setiap satu rupiah modal saham atau ekuitas yang ditanamkan pada perusahaan akan memberikan keuntungan bersih sebesar 13,48\%.

Rasio ROE tahun 2019 jika dibandingkan dengan tahun 2018 mengalami penuruan sebesar 2,32\%, Tetapi jika dilihat secara jumlah nilai uang menunjukkan bahwa laba bersih tahun 2019 tumbuh sebesar 11,98\%. Modal saham tahun 2019 jika dibandingkan tahun 2019 meningkat sebesar $14,63 \%$.

Hasil Analisis net profit margin, rasio tertinggi terjadi di tahun 2018, yaitu sebesar 24,77\%. Bahwa setiap satu rupaih pendapatan bersih akan memberikan laba bersih sebesar $24,77 \%$. Net profit margin menunjukkan kemampuan perusahaan menghasilkan laba yang tinggi pada tingkat penjualan/pendapatan tertentu. Net profit margin tahun 2019 menunjukkan hasil sebesar 24,00\%, mengalami penurunan sebesar $3,11 \%$ terhadap tahun 2018.

Tetapi jika dilihat dari sisi jumlah nilai uang, tahun 2019 perusahaan membukukan pendapatan usaha sebesar 13,36 triliun rupiah dan pada tahun 2018 membukukan sebesar 11,46 triliun rupiah, sehingga pendapatan usaha perusahaan di tahun 2019 naik sebesar $16,58 \%$

Sementara dari sisi laba bersih tahun 2018 mencatat sebesar 2,78 triliun rupiah dan tahun 2019 berhasil membukukan laba bersih 3,11 triliun rupiah.

Dari perhitungan yang dilakukan terhadap rasio profitabilitas menunjukkan bahwa PT. Pegadaian (Persero) dalam rentang waktu 2015 sampai 2019 memiliki kemampuan untuk menciptakan laba.

\section{Rasio Solvabilitas}

Tabel 3. Rasio Solvabilitas

\begin{tabular}{ccc}
\hline Tahun & Debt to Total Asset & $\begin{array}{c}\text { Debt to } \\
\text { Equity }\end{array}$ \\
\hline 2015 & 0.68 & 2.12 \\
\hline 2016 & 0.65 & 1,84 \\
\hline 2017 & 0.63 & 1,67 \\
\hline 2018 & 0,62 & 1,62 \\
\hline 2019 & 0,65 & 1,83 \\
\hline \multicolumn{2}{l}{ Sumber: Olahan Data }
\end{tabular}

Tabel 3 menunjukkan perbandingan hasil analisis ratio solvabilitas yaitu debt to total asset dan ratio debt to equity dari tahun 2015 sampai tahun 2019

Analisis rasio dari perhitungan debt to total asset menunjukkan bahwa hasil rasio tertinggi terjadi di tahun 2015, yaitu sebesar 0,68. Artinya setiap 68 rupiah hutang dijamin oleh 100 rupiah asset. Rasio terendah terjadi pada tahun 2018 yaitu sebesar 0,62, dimana setiap 62 rupiah hutang dijamin oleh asset sebanyak 100 rupiah.

Rasio debt to total asset sepanjang tahun 2015 sampai tahun 2019 menunjukkan perusahan sangat mampu untuk membayar kewajiban hutang jangka pendek maupun jangka panjang dari total asset perusahaan, atau dengan kata lain total asset perusahaan dari tahun 2015 sampai tahun 2019 memiliki jumlah yang lebih besar dari pada total hutang.

Dalam mendanai usahanya, perusahaan pada umumnya memiliki beberapa sumber dana. Sumber dana yang dapat diperoleh dari hutang atau dari setoran modal sendiri. Analisis rasio debt to total equity sepanjang tahun 2015 sampai tahun 2019 memperlihatkan sumber pendanaan perusa-haan dari hutang jauh lebih besar dibandingkan dengan setoran modal sendiri. 
Hasil rasio debt to total equity pada tahun 2019 sebesar 1,83, artinya 183 rupiah hutang hanya dijamin oleh 100 rupiah dari modal sendiri. Ratio tertinggi terjadi pada tahun 2015, yaitu sebesar 2,12 dan terendah terlihat pada tahun 2018 yaitu sebesar 1,62 .

Dari perhitungan yang dilakukan terhadap rasio solvabilitas menunjukkan bahwa PT. Pegadaian (Persero) dalam rentang waktu 2015 sampai 2019 memiliki kemampuan membayar kewajiban jangka pendek maupun jangka panjang yang segera jatuh tempo dari total asset yang dimiliki perusahaan.

\section{Rasio Pertumbuhan}

Tabel 4. Rasio Pertumbuhan

\begin{tabular}{|c|c|c|c|}
\hline Thn & $\begin{array}{c}\text { Operating } \\
\text { Revenues }\end{array}$ & $\begin{array}{c}\text { Operating } \\
\text { Profit }\end{array}$ & $\begin{array}{c}\text { Total } \\
\text { Assets }\end{array}$ \\
\hline 2015 & $14,52 \%$ & $12,57 \%$ & $10,48 \%$ \\
\hline 2016 & $8,67 \%$ & $15,15 \%$ & $19,70 \%$ \\
\hline 2017 & $8,39 \%$ & $11,26 \%$ & $3,87 \%$ \\
\hline 2018 & $8,95 \%$ & $8,89 \%$ & $8,43 \%$ \\
\hline 2019 & $16,54 \%$ & $15,79 \%$ & $23,74 \%$ \\
\hline
\end{tabular}

Sumber: Olahan Data

Tabel 4, menunjukkan hasil perhitungan dari rasio pertumbuhan (growth ratio), yang terdiri dari pertumbuhan operating revenues, operating profit dan pertumbuhan total asset.

Hasil analisis operating revenues selalu ada peningkatan atau pertumbuhan jika dibandingkan dengan tahun sebelumnya. Pertumbuhan tertinggi terjadi di tahun 2015 dan tahun 2019 yang mencapai angka 2 digit.

Pada tahun 2019 perusahaan mampu membukukan pendapatan usaha bersih senilai 13,36 triliun rupiah, naik sebesar $16,54 \%$ dibandingkan tahun 2018 senilai 11,46 triliun rupiah.

Untuk pertumbuhan operating profit tahun 2015, 2016, 2017 dan tahun 2019 mencapai angka 2 digit. Tahun 2019 perusahaan mampu membukukan laba usaha senilai 4,21 triliun rupiah, naik sebesar $15,79 \%$ dibandingkan tahun 2018 yang membukukan laba usaha sebesar 3,63 triliun rupiah.

Dari hasil analisi data, operating profit setiap tahunnya selalu mengalami peningkatan atau pertumbuhan.

Berikutnya untuk analisis pertumbuhan total asset, juga menunjukkan kondisi yang memuaskan. Setiap tahun terjadi peningkatan jumlah total asset perusahaan. Peningkatan asset tertinggi terjadi pada tahun 2016 dan tahun 2019 dengan rasio peningkatan masing-masing sebesar $19,70 \%$ dan 23,74\%.

Berdasarkan laporan keuangan perusahaan 2019, jumlah total asset perusahaan senilai 65,32 triliun rupiah, naik sebesar $23,74 \%$ dibandingkan total asset perusahaan tahun 2018 senilai 52,79 triliun rupiah.
Secara keseluruhan rasio pertumbuhan perusahaan dari tahun 2015 sampai tahun 2019 memperlihatkan hasil yang positif, dimana selalu mengalami peningkatan dari sisi jumlah untuk setiap periodenya. Hal ini menunjukkan bahwa PT. Pegadaian (Persero) sepanjang tahun 2015 sampai tahun 2019 memiliki kemampuan dalam mempertahankan posisi ekonominya ditengah persaingan usaha yang ketat, dan memunjukkan pula kemampuan perusahaan untuk terus bertumbuh.

\section{KESIMPULAN}

Laporan keuangan PT. Pegadaian (Persero) dalam rentang waktu 2015 sampai 2019, apabila dilihat dari rasio profitabilitas menunjukkan kinerja keuangan yang positif. Ditengah persaingan bisnis sejenis yang semakin ketat di tahun 2019, perusahaan masih mampu membukukan laba.

Hasil analisis terhadap rasio solvabilitas PT. Pegadaian (Persero), dalam kurun waktu 2015 sampai 2019, menunjukkan bahwa laporan keuangan perusahaan dalam kondisi solvabel, yang berarti bahwa PT. Pegadaian (Persero) mempunyai asset yang cukup untuk membayar semua kewajiban jangka pendek maupun kewajiban jangka panjang.

Kemudian dari analisis rasio pertumbuhan dalam rentang waktu 2015 sampai 2019, menunjukkan pula akan kemampuan perusahaan dalam meningkatkan pertumbuhan pendapatan usaha, laba usaha, dan pertumbuhan asset perusahaan.

Di tengah stagnasi perekonomian nasional 2019, PT. Pegadaian (Persero) mampu membukukan kinerja keuangan yang cukup bagus. Perusahaan yang memiliki slogan "Mengatasi Masalah Tanpa Masalah", di akhir tahun 2019 mampu mening-katkan pertumbuhan pendapatan usaha sebesar $16,54 \%$, laba bersih sebesar $11,98 \%$ dan pertum-buhan asset sebesar $23,74 \%$.

Kinerja positif yang diraih dari tahun 2015 sampai 2019, tentunya tidak terlepas dari kontribusi seluruh nasabah yang selalu setia menggunakan produk dan layanan dari PT. Pegadaian (Persero).

Untuk terus meningkatkan kinerja keuangan perusahaan pada tahun-tahun kedepan, hendaknya PT. Pegadaian (Persero) untuk terus berinovasi dalam pelayanan berbasis digital dan hendaknya pula terus melahirkan inovasi-inovasi baru yang memudahkan nasabah berinteraksi maupun bertransaksi dengan perusahaan. Tentunya inovasi tersebut harus mengarah pada efisiensi cost dan berfokus pada peningkatan produktivitas perusa-haan. Hal ini menjadi penting supaya PT. Pegadaian (Persero) di tahun-tahun mendatang menjadi agen keuangan pilihan utama seluruh rakyat Indonesia. 


\section{REFERENSI}

Barus, M. A.;Sudjana, N.;\& Sulasmiyati, S. (2017). Penggunaan Rasio Keuangan Untuk Mengukur Kinerja Keuangan Perusahaan (Study pada PT. Astra Otoparts, Tbk dan PT. Goodyear Indonesia, Tbk yang Go Public di Bursa Efek Indonesia). Jurnal Administrasi Bisnis (JAB) , 44 No.1 Maret 2017, 154 - 163.

Fahmi, I. (2011). Analisis Laporan Keuangan. Bandung: Alfabeta.

Fahmi, I. (2012). Analisis Laporan Keuangan. Bandung: Alfa Beta.

Harjito, A.;\& Martono. (2011). Manajemen Keuangan (Kedua p.). Yogyakarta: Ekonisia Universitas Islam Indonesia.

Hery. (2012). Akuntansi Keuangan Menengah 1. Jakarta: PT. Bumi Aksara.

https://wikipedia.org. (25. $4 \quad 4$ 2020). id.wikipedia.org/wiki/. Haettu 25. 42020 osoitteesta id.wikipedi.org: id.wikipedia.org/wiki/pegadaian(perusahaan)\#pengertian

https://www.pegadaian.co.id. (25. $4 \quad$ 2020). https://www.pegadaian.co.id. Haettu 25. 4 2020 osoitteesta pegadaian.co.id: pegadaian.co.id/laporan-kinerja/laporan tahunan

Ikatan Akuntan Indonesia. (2009). Standar Akuntansi Keuangan: PSAK No. 1 - Penyajian Laporan Keuangan. Jakarta: Salemba Empat.
Jumingan. (2006). Analisis Laporan Keuangan (Pertama p.). Jakarta: PT. Bumi Aksara.

Kasmir. (2010). Analisis Laporan Keuangan (ke-3 p.). Jakarta: PT. Rajagrafindo Persada.

Kuncoro, M. (2009). Metode Riset Untuk Bisnis dan Ekonomi. Jakarta: Erlangga.

Maith, H. A. (2013). Analisis Laporan Keuangan Dalam Mengukur Kinerja Keuangan Pada PT. Hanjaya Mandala Sampoerna TBK. EMBA , 1 No.3 (September 2013), 619-628.

Munawir. (2012). Analisis Informasi Keuangan. Yogyakarta: Liberty.

Munawir. (2007). Analisis Laporan Keuangan (Kedua p., Vuosik. Pertama). Yogyakarta: Liberty.

Riyanto, B. (2001). Dasar Dasar Pembelanjaan Perusahaan (Keempat p., Vuosik. Cetakan Ketujuh). Yogyakarta: BPFE Yogyakarta.

Sartono, A. (2011). Manajemen Keuangan (Teori dan Aplikasi). Yogyakarta: BPFE Yogyakarta.

Srimindarti. (2006). Balanced Scorecard Sebagai Alternatif Untuk Mengukur Kinerja. Semarang: STIE Stikubank.

Sutrisno. (2009). Manajemen Keuangan Teori, Konsep Dan Aplikasi. Yogyakarta: Ekonisia.

www.kontan.co.id. (4. September 2018). www.kontan.co.id. (N. Indrastiti, Toimittaja) Haettu 5. September 2020 osoitteesta Kontan.Co.id: https://keuangan.kontan.co.id/news/kalahsaing-dari-fintech-bisnis-pegadaian-swastaturun-73 